\title{
TAFSIR GENDER
}

\author{
Oleh: \\ Tri Wahyudi Ramdhan \\ Sekolah Tinggi Agama Islam Darul Hikmah Bangkalan \\ wahyudi@darul-hikmah.com
}

\begin{abstract}
Traditional Islamic thought in general provides limited role of women as wives and mothers. Based on the view of classical Islamic texts and literature are still seen that women are still marginalized, or in other words, women are still under the domination of men. Therefore, women need to construct a discourse or text at will. It is undeniable that the interpretation of the classical scholars on the concept of equality of men and women from the perspective of today may well be judged as biased. For interpretations of the past can not be released to the socio-historical context of the time. Departing from the problems mentioned above then this article would like to see and analyze how the concepts offered and presented Islam in view of gender equality between men and women starting from the concept of gender so that the concept of gender bias by sex.Selanjutnyan followed by a discussion of the word gender mufrodat in the Qur'an and concludes with the interpretation of the discourse of gender equality. Dalama This commentary will set forth the extent where the equality between men and women
\end{abstract}

Key words: Gender, patriarkhi, Feminisme, Emansipasi

\section{A. Pendahuluan}

Saat ini gender masih menjadi isu sentral yang kerap dibicarakan. Kekeliruan dalam memahami dan mengartikan istilah gender masih sering terjadi. Sebagaimana isu-isu lainnya seperti Demokrasi, HAM, Civil Society, Gender termasuk isu baru dan diperkirakan menjadi discourse di Indonesia barulah pada pertengahan tahun 1990-an. Sedangkan kesetaraan gender berarti kesamaan kondisi bagi laki-laki dan perempuan untuk memperoleh kesempatan serta hak-haknya sebagai manusia. Kesetaraan gender meliputi penghapusan diskriminasi dan ketidakadilan struktural, baik terhadap laki-laki maupun perempuan. Dengan keadilan gender berarti tidak ada pembakuan peran, beban ganda, subordinasi, marginalisasi dan kekerasan terhadap perempuan maupun laki-laki. Terwujudnya kesetaran dan keadilan gender ditandai dengan tidak adanya diskriminasi antara perempuan dan laki-laki, dan dengan 
demikian mereka memiliki akses dan kesempatan berpartisispasi.

Kaum perempuan seringkali kurang mendapatkan kesempatan yang cukup untuk berkiprah dalam kehidupan sosial bila dibandingkan dengan laki-laki. Hal ini terjadi karena masih lekatnya ketidakadilan gender dalam masyarakat yang terjelmakan dalam marginalisasi atau proses pemiskinan ekonomi, subordinasi atau anggapan yang bersifat menyepelekan (tidak penting) kepada kaum perempuan, bahkan kekerasan (violence) termasuk dalam hal bekerja atau justru beban kerja yang lebih panjang atau lebih banyak (double burden). Bentuk ketidakadilan gender ini tidak dapat dipisah-pisahkan karena saling terkait dan berhubungan, serta saling mempengaruhi secara dialektis. Tidak ada satu pun bentuk ketidakadilan gender yang lebih penting dan lebih esensial dari ketidakadilan yang lain.

Begitu juga dalam bidang keagamaan, khususnya masyakarat Islam. Fenomena ketidakadilan gender dalam Islam ternyata lebih menunjukkan adanya kesewenang-wenangan dan penindasan terhadap kaum perempuan. Boleh jadi hal ini merupakan akibat dari pola budaya dan sistem masyarakat muslim yang mayoritas bercorak patrialkal, struktural dan subordinatif. Hal ini dapat dilihat dalam sejarah masyarakat muslim. Sempitnya ruang gerak bagi kaum perempuan muslim terjadi justru setelah Islam mengalami perkembangan pesat dengan wilayah kekuasaan yang luas. Dalam masyarakat muslim Arab pra-Islam dan Islam masa awal, kaum perempuan pada umumnya dapat beraktualisasi secara bebas. Namun, kemudian terjadi pergeseran pandangan terhadap perempuan diantaranya karena interaksi budaya, kepentingan politik dan ekonomi serta interpretasi atau penafsiran terhadap teks-teks al-Qur'an.

Apabila gender dipahami sebagai konstruksi sosial, maka agama dipandang sebagai salah satu institusi yang membentuk pandangan yang streotif terhadap perempuan. Dalam hal ini, Islam dituduh sebagai agama yang paling tidak adil memperlakukan perempuan. Pandangan-pandangan yang bias gender telah mengakar dalam wacana dan praktek keberagamaan dengan atau tanpa legitimasi ajaran agama, akan menjadi lebih sulit untuk dibongkar atau didekonstruksi jika peran-peran dari tiap elemen masyarakat terutama kyai sebagai tokoh agama tidak diperhitungkan.

Dalam konsep Islam, terutama merujuk kepada al-Qur'an, konsep keseteraan gender mengisyaratkan 2 (dua) pengertian. Pertama, al-Qur'an mengakui martabat pria dan wanita dalam kesejajaran tanpa membedakan jenis kelamin. Kedua, pria dan wanita mempunyai hak dan kewajiban yang sejajar disegala bidang. akan tetapi pandangan inferior

80 JURNAL LISAN AL-HAL 
bahwa perempuan adalah makhluk yang lemah juga disosialisasikan atas nama agama.

Memahami ajaran agama melalui penafsiran al-Qur'an sebagaimana yang ditafsirkan ulama salaf tidak sepenuhnya benar. Artinya kondisi sosial masyarakat tidak lagi seperti pada masa dulu. Bukan saja karena alQur'an harus diyakini berdialog dengan setiap generasi, namun juga harus dipelajari dan dipikirkan. Sementara hasil pemikiran (termasuk penafsiran) selalu dipengaruhi oleh beberapa faktor, misalnya kondisi pengalaman, ilmu pengetahuan, latar belakang pendidikan yang berbeda dari satu generasi ke generasi lainnya, bahkan antara pemikir satu dan pemikir lainnya pada suatu generasi.

Dalam khazanah demokrasi terdapat aliran yang mngusung semboyan kesetaraan gender dan persamaan hak antara laki-laki dan perempuan di segala bidang. Dalam perkembangannya, mereka berhasil mempengaruhi pemikiran dunia. Bahkan disebagian negara-negara islam, aliran ini mulai digemari. Karena bilaa dilihat sepintas, nilai-nilai emansipasi yang menjadi ruh perjuangan mereka sangatlah menjajikan bagi terhapusnya diskriminasi wanita dan bagi terciptanya keadilan yang tidak mempermasalahkan perbedaan gender. Lebih lanjut, para tokoh feminis muslim juga melakukan kritik terhadap interpretasi teks-teks suci yang diputarbalikkan sedemikian rupa sehingga berakibat munculnya kehidupan yang eksploitatif dan diskriminatif terhadap perempuan. Kritik tersebut terutama ditujukan terhadap tafsiran fikih Islam yang memposisikan wanita pada posisi yang subordinat.

Beberapa teori mengenai kesetaraan peran laki-laki dan perempuan yang umumnya dikemukakan oleh para feminis kontemporer didasarkan pada pertanyaan mendasar "apa peran perempuan?" Secara esensial ada empat jawaban untuk pertanyaan tersebut. Pertama, bahwa posisi dan pengalaman perempuan dari kebanyakan situasi berbeda dari yang dialami laki-laki dalam situasi tu. Kedua, posisi perempuan dalam kebanyakan situasi tak hanya berbeda, tetapi juga kurang menguntungkan atau tak setara dibandingkan dengan laki-laki. Ketiga, bahwa situasi perempuan harus pula dipahami dari sudut hubungan kekuasaan langsung antara laki-laki dan perempuan. Perempuan "ditindas", dalam arti dikekang, disubordinasikan, dibentuk, dan digunakan, serta disalahgunakan oleh laki-laki. Keempat perempuan mengalami perbedaan, ketimpangan dan berbagai penindasan berdasarkan posisi total mereka dalam susunan stratifikasi atau faktor penindasan dan hak istimewa berdasar kelas, ras, etnisitas, umur, status perkawinan, dan posisi global. Masing-masing berbagai tipe teori feminis itu dapat digolongkan sebagai 
teori perbedaan gender, atau teori ketimpangan gender, atau teori penindasan gender, atau teori penindasan sruktural. ${ }^{1}$

Sementara itu pemikiran Islam tradisional yang direfleksikan oleh kitab-kitab fiqh secara general memberikan keterbatasan peran perempuan sebagai istri dan ibu. Menurut pemikiran Islam tradisional tersebut bahwa prinsip utamanya adalah bahwa "laki-laki adalah kepala keluarga" dan bertanggung jawab terhadap persoalanpersoalan luar rumah, sedangkan perempuan sebagai istri, bertanggung jawab untuk membesarkan anak dan pelayanan-pelayanan domestik lainnya. Perbedaan ini menjadi titik tolak ukur dari perbedaan peran laki-laki dan perempuan.

Berdasarkan pandangan teks dan literature Islam klasik tersebut masih terlihat bahwa kaum perempuan masih termarjinalkan, atau dengan kata lain perempuan masih berada di bawah dominasi laki-laki. Oleh karenanya, wacana atau konstruk perempuan harus menurut kehendak teks. Tak dapat dipungkiri bahwa penafsiran ulama-ulama klasik tentang konsep persamaan laki-laki dan perempuan jika dilihat dari perspektif saat ini bisa saja dinilai sebagai bias. Sebab penafsiran-penafsiran masa lampau itu tidak dapat dilepaskan dengan konteks sosio-historis saat itu. ${ }^{2}$

Berangkat dari permasalahan tersebut di atas maka tulisan ini ingin melihat dan menganalisa bagaimana konsep yang ditawarkan dan dikemukakan Islam dalam memandang kesetaraan gender antara laki-laki dan perempuan.

\section{B. Pembahasan}

\section{Konsep Gender}

Dalam bahasa Inggris, kata gender diartikan sebagai "jenis kelamin", atau sinonim dengan kata sex. Untuk konsep yang lebih luas, gender diartikan sebagai "gender is a basis for beginning the different contributions that man and woman make to culture and collective life by distinction which they are as man and woman." Sedangkan kesetaraan gender berarti kesamaan kondisi bagi laki-laki dan perempuan untuk memperoleh kesempatan serta hak-haknya sebagai manusia. Kesetaraan gender meliputi penghapusan diskriminasi dan ketidakadilan struktural, baik terhadap laki-laki maupun perempuan. Dengan keadilan gender

${ }^{1}$ George Ritzer and Douglas J. Goodman, Modern Sociological Theory, $6^{\text {th }}$ Edition, diterjemahkan, Teori Sosiologi Modern, oleh Alimandan (Jakarta: Prenada Media, 2003), hlm. 414-416.

2 Faisar Ananda Arfa, Wanita dalam Konsep Islam Modernis, (Jakarta: Pustaka Firdaus, 2004), hlm. 11. 
berarti tidak ada pembakuan peran, beban ganda, subordinasi, marginalisasi dan kekerasan terhadap perempuan maupun laki-laki.

Konsep penting yang perlu dipahami dalam rangka membahas hubungan kaum perempuan dan laki-laki adalah membedakan antara konsep sex (jenis kelamin) dan konsep gender. Pemahaman dan pebedaan antara kedua konsep tersebut sangat diperlukan dalam melakukan analisis untuk memahami persoalan-persoalan ketidakadilan sosial yang menimpa kaum perempuan. Hal ini disebabkan karena ada kaitan yang erat antara perbedaan gender (gender differences) dan ketidakadilan gender (gender inequalities) dengan struktur ketidakadilan masyarakat secara luas. Pemahaman atas konsep gender sangatlah diperlukan mengingat dari konsep ini telah lahir suatu analis gender. ${ }^{3}$

Istilah gender digunakan berbeda dengan sex. Gender digunakan untuk mengidentifikasi perbedaan laki-laki dan perempuan dari segi sosial-budaya. Sementara sex digunakan untuk mengidentifikasi perbedaan laki-laki dan perempuan dari segi anatomi biologi. Istilah sex lebih banyak berkonsentrasi pada aspek biologi seseorang, meliputi perbedaan komposisi kimia dan hormon dalam tubuh, anatomi fisik, reproduksi, dan karakteristik biologis lainnya. Sementara itu, gender lebih banyak berkonsentrasi kepada aspek sosial, budaya, psikologis, dan aspekaspek non-biologis lainnya. ${ }^{4}$

Perbedaan tersebut melahirkan pemisahan fungsi dan tanggung jawab antara laki-laki dan perempuan. Laki-laki bertugas mengurusi urusan luar rumah dan perempuan bertugas mengurusi urusan dalam rumah yang dikenal sebagai masyarakat pemburu (hunter) dan peramu (gatherer) dalam masyarakat tradisional dan sektor publik dan sektor domestik dalam masyarakat modern. ${ }^{5}$ Perbedaan gender (gender differences) pada proses berikutnya melahirkan peran gender (gender role) dan dianggap tidak menimbulkan masalah, maka tak pernah digugat. Akan tetapi yang menjadi masalah dan perlu digugat adalah struktur ketidakadilan yang ditimbulkan oleh peran gender dan perbedaan gender. ${ }^{6}$

Dalam pergaulan sehari-hari dalam masyarakat yang menganut

\footnotetext{
3 Mansour Fakih, Analisis Gender dan Transformasi Sosial, (Yogyakarta: Pustaka Pelajar, 1997), hlm. 4.

4 Nasaruddin Umar, Argumen Kesetaraan Jender Perspektif Al-Qur'an (Jakarta: Paramadina, 1999), hlm. 35.

${ }^{5}$ Mansour Fakih., hlm. 302-302.

6 Nur Ahmad Fadhil Lubis, Yurisprudensi Emansipatif, (Bandung: Citapustaka Media, 2003), hlm. 47.
} 
perbedaan gender, ada nilai tata krama dan norma hukum yang membedakan peran laki-laki dan perempuan. Setiap orang seolah-olah dituntut mempunyai perasaan gender (genderfeeling) dalam pergaulan, sehingga jika seseorang menyalahi nilai, norma dan perasaan tersebut maka yang bersangkutan akan menghadapi risiko di dalam masyarakat. Predikat laki-laki dan perempuan dianggap sebagai simbol status. Lakilaki diidentifikasi sebagai orang yang memiliki karekteristik kejantanan (masculinity), sedangkan perempuan diidentifikasi sebagai orang yang memiliki karekteristik kewanitaan (femininity). Perempuan dipersepsikan sebagai wanita cantik, langsing, dan lembut, sebaliknya laki-laki dipersepsikan sebagai manusia perkasa, tegar dan agresif.

Sementara perempuan ditempatkan pada posisi inferior. Peran mereka terbatas sehingga akses untuk memperoleh kekuasaan juga terbatas, akibatnya perempuan mendapatkan status lebih rendah dari laki-laki. Sebagai ibu atau sebagai istri mereka memperoleh kesempatan yang terbatas untuk berkarya di luar rumah. Penghasilan mereka sangat tergantung pada kerelaan laki-laki, meskipun bersama dengan anggota keluarganya merasakan perlindungan yang diperoleh dari suaminya hakhak yang diperolehnya jauh lebih terbatas daripada hak-hak yang dimiliki suaminya. ${ }^{7}$

Menurut Ritzer dan Goodman, ada empat tema yang menandai teori ketimpangan gender. Pertama, laki-laki dan perempuan diletakkan dalam masyarakat tak hanya secara berbeda, tetapi juga timpang. Secara spesifik, perempunan memperoleh sumber daya material, status sosial, kekuasaan dan peluang untuk mengaktualisasikan diri lebih sedikit daripada yang diperoleh laki-laki yang membagi-bagi posisi sosial mereka berdasarkan kelas, ras, pekerjaan, suku, agama, pendidikan, kebangsaan atau berdasarkan faktor sosial penting lainnya. Kedua, ketimpangan gender berasal dari organisasi masyarakat, bukan dari perbedaan biologis atau kepribadian penting antara laki-laki dan perempuan. Ketiga, meski manusia secara individual memiliki perbedaan ciri dan karakter satu sama lain, namun tidak ada pola perbedaan alamiah signifikan yang membedakan laki-laki dan perempuan. Pengakuan akan ketimpangan gender berarti secara langsung menyatakan bahwa perempuan secara situasional kurang berkuasa dibanding lakilaki untuk memenuhi kebutuhan mereka bersama laki-laki dalam rangka pengaktualisasian diri. Keempat,semua teori ketimpangan gender menganggap laki-laki maupun

7 Nasaruddin Umar, Argumen Kesetaraan Jender Perspektif Al-Qur'an (Jakarta: Paramadina, 1999), hlm. 75.

84 JURNAL LISAN AL-HAL 
perempuan akan menanggapi situasi dan struktur sosial yang semakin mengarah ke persamaan derajat (egalitarian) dengan mudah dan secara ilmiah. Dengan kata lain, mereka berkeyakinan akan adanya peluang untuk mengubah situasi. ${ }^{8}$

Kesetaraan antara laki-laki dan perempuan dalam sebuah keluarga, bukan berarti memposisikan laki-laki dan perempuan harus diperlakukan sama. Memperlakukan laki-laki dan perempuan secara sama dalam semua keadaan justru menimbulkan bias gender. Memperlakukan sama antara laki-laki dan perempuan dalam kerja rumah tangga pada satu keadaan, misalnya, suami juga berkewajiban mengurus anaknya, sama halnya istri mempunyai kewajiban mengurus anaknya. Artinya keajiban mengurus anak tidak mutlak menjadi kewajiban istri semata, tetapi merupakan kewajiban bersama.

Menurut Budhy Munawar Rachman, terjadinya bias gender salah satunya disebabkan tema patriarkhi (kekuasaan kaum laki-laki), yang hal ini menjadi agenda yang paling besar digugat oleh kaum feminisme Islam. Karena patriarhki dari sudut feminisme dianggap sebagai asal usul dari seluruh kecenderungan misoginis (kebencian terhadap kaum perempuan) yang mendasaripenulisan-penulisan teks keagamaan yang bias kepentingan laki-laki. ${ }^{9}$

Kekerasan terhadap perempuan selalu terjadi di antaranya disebabkan beberapa faktor yaitu:

a. Ideologi patriarkhi dan budaya patriarkhi. Di mana laki-laki superior (penguasa perempuan) dan perempuan inferior.

b. Faktor struktur hukum yang meliputi substansi hukum (berisi semua peraturan perundang-undangan) baik tertulis maupun tidak tertulis yang berlaku bagi lembaga tinggi negara maupun warga negara, struktur hukum (penegak hukum, polisi, jaksa, hakim, pengacara dan prosedur penegakannya), budaya hukum

c. Faktor interpretasi agama dan budaya ${ }^{10}$

Konsep patriarki berbeda dengan patrilinial. Patrilinial diartikan sebagai budaya di mana masyarakatnya mengikuti garis laki-laki seperti anak bergaris keturunan ayah, contohnya Habsah Khalik; Khalik adalah nama ayah dari Habsah. Sementara patriarki memiliki makna lain yang secara harfiah berarti "kekuasaan bapak" (role of the father) atau

\footnotetext{
${ }^{8}$ George Ritzer and Douglas J. Goodman,... hlm. 420.

${ }^{9}$ Budhy Munawar Rachman, Islam Pluralis Wacana Kesetaraan Kaum Beriman, (Jakarta: Paramadina), hlm. 394. 144.

${ }^{10}$ Elfi Muawanah, Menuju Kesetaraan Gender, (Malang: Kutub Minar, 2006), hlm.
} 
"partiakh" yang ditujukan untuk pelabelan sebuah "keluarga yang dikuasai oleh kaum laki-laki”. Secara terminologi kata patriarki digunakan untuk pemahaman kekuasaan laki-laki, hubungan kekuasaan dengan apa lakilaki menguasai perempuan, serta sistem yang membuat perempuan tetap dikuasai melalui bermacam-macam cara. ${ }^{11}$

Lebih lanjut menurut Budhy secara etimologis konsep tersebut berkaitan dengan sistem sosial, dimana sang ayah menguasai semua anggota keluarganya, harta miliknya serta sumber-sumber ekonomi. Ia juga yang membuat semua keputusan penting keluarga. Sistem berdasarkan patriarkhi ini biasanya mengasingkan perempuan di rumah, dengan demikian laki-laki lebih bisa menguasai kaum perempuan. Sementara itu pengasingan perempuan di rumah menjadikan perempuan tidak tidak mandiri secara ekonomis, dan selanjutnya tergantung secara psikologis. Norma-norma moral, sosial dan hukum pun lebih banyak memberi hak kepada kaum laki-laki daripada kaum perempuan, justru karena alasan bahwa kaum laki-laki memang lebih bernilai secara publik daripada perempuan. Dalam perkembangannya patriarkhi ini sekarang telah menjadi istilah terhadap semua sistem kekeluargaan maupun sosial, politik dan keagamaan yang merendahkan, bahkan menindas kaum perempuan mulai dari lingkungan rumah tangga hingga masyarakat. ${ }^{12}$

\section{Bahasa Gender dalam al-Quran}

Identitas gender dalam al-Quran dapat dipahami melalui simbol dan bentuk gender yang digunakan di dalamnya, dalam permasalahan ini akan digunakan pendekatan sintaksis sebagai langkah awal untuk memahami secara struktural istilah gender yang termaktub dalam alQuran, Antara lain, al-rijal (laki-laki) dan an-Nisa. (perempan), kata arrajuli berasal dari kata رج ل J bentuk jamak dari rijal-al yang derevasinya membentuk beberapa kata, seperti rajala (mengikat), rajila (yang berjalan kaki), rijlun (kaki, sekawanan ikan, zaman, kesengsaraan), al-rijlah (tumbuhtumbuhan), dan ar-rajulu (orang laki-laki) ${ }^{13}$

Kata al-rajul dalam berbagai bentuknya terulang sebanyak 55 kali dalam alQuran ${ }^{14}$, dari semua kata itu dapat dibedakan mejadi dua makna,.

11 Kamala Bashin, What is Patriarchy, Diterjemahkan "Menggugat Patriarki" oleh Nursyahbani Katjasungkana, (Yogyakarta: Yayasan Bentang Budaya, 1996), hlm. 29.

12 Budhy Munawar Rachman, Islam Pluralis Wacana Kesetaraan Kaum Beriman, (Jakarta: Paramadina), hlm. 394.

13 Atabik ali dan Ahmad Zuhdi Muhdhor, Kamus Kontemporer Arab-Indonesia, (Yogyakarta: Multi Karya Grafika, 1998), cet. Kelima, hlm. 961.

${ }^{14}$ Nasarudin Umar, Argumen Kesetaraan Jender Perspektif Al-Quran, (Jakarta: Dian 
Pertama Al-rajul dalam arti gender laki-laki, seperti dalam Q.S al Baqoroh : 282,

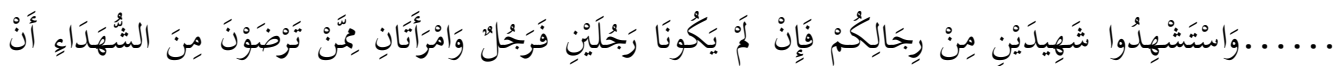

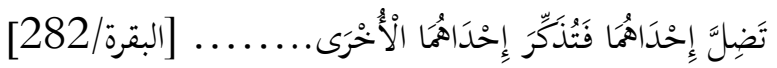

"Dan persaksikanlah dengan dua orang saksi dari orang-orang lelaki (di antaramu). Jika tak ada dua oang lelaki, Maka (boleh) seorang lelaki dan dua orang perempuan dari saksi-saksi yang kamu ridhai, supaya jika seorang lupa Maka yang seorang mengingatkannya".

Lafazh مِنْ ِ رِجالِكُمْم pada ayat ditekankan pada aspek gender laki-laki bukan kepada aspek biologisnyanya sebagai manusia yang berjenis kelamin laki-laki. Dimana dalam keterangan ayat tersebut bahwa tidak semua berjenis laki-laki mempunyai kualitas persaksian yang sama. Ayat ini bisa dimengerti, mengingat masyarakat Arab ketika ayat ini turun, perempuan tidak pernah diberikan kesempatan untuk menjadi saksi karena tidak representative. Mengenai perbandingan Persaksian, seorang laki-laki sebanding dengan dua orang perempuan, menurut Muhammad Abduh dalam tafsir al-manar menyatakan bahwa hal ini merupakan pendapat yang dapat dimaklumi, karena tugas dan fungsi perempuan ketika itu hanya disibukkan dengan urusan rumah tangga saja, sementara laki-laki bertugas untuk urusan-urusan social ekonomi di luar rumah. Bukannya perempuan lemah ingatan dan kecerdasannya dibanding lakilaki 15, dan apabila dikontekskan pada saat ini perempuan telah memperlihatkan kepiawaian dalam berbagai lini.

Tetapi az- Zuhaili sedikit berbeda pendapat mengenai ayat ini,menurutnya di hadapan Allah SWT porsi peran publik yang sama antara pria dan wanita adalah sama. Tetapi karena ada suatu fungsi yang berbeda antara keduanya yang bereda mengharuskan keduanya menepati fungsinya masing-masing. Karena pertimbangan faktor alamiyah yang secar kodrati wanita mempunyai kewajiban melahirkan menyusui dan mengasuh anak serta kekurangan dalam hal fisik yang lembut dan bermental tipis (Naqishah al-Aqli), untuk itu wanita dalam persaksian tidak sama porsinya dengan laki-laki. ${ }^{16}$

Rakyat, 2010), Cet. II, hlm. 131.

15 Ibid, hlm. 133. hlm. 486.

16 Wahbah az-Zuhaili, Fiqh al-Islamiy wa Adilatuh vol. 6 (Beirut: Dar al-Fikr, 1989), 
Disisi lain syaikh zamakhsyari memaparkan bahwa konsep persaksian laki-laki ataupun perempuan hendaknya dilakukan secara proporsional yakni dengan mengacu nilai-nilai humanistik dan keadilan apabila perempuan menjadi saksi hendaknya ia dihadirkan secara berdua, hal ini mengindikasikan bahwa persaksian perempuan akan lebih kuat dan paten apabila dihadirkan secara berdua sebagai wujud penguat satu dengan lainnnya ${ }^{17}$

Kedua, Al-rajul dalam arti yang sama antara laki-laki maupun perempuan, Q.S al-Ahzab :23

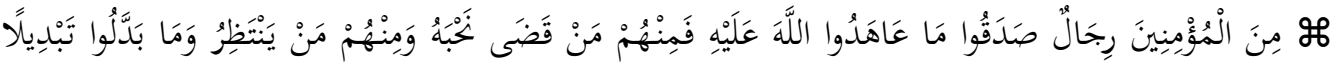

$$
\begin{aligned}
& \text { (23) [الأحزاب/23] }
\end{aligned}
$$

"Di antara orang-orang mukmin itu ada orang-orang yang menepati apa yang telah mereka janjikan kepada Allah; Maka di antara mereka ada yang gugur. dan di antara mereka ada (pula) yang menunggu- nunggu dan mereka tidak merobah (janjinya,

Istilah رِجَالْpada ayat di atas tidak hanya menunjukkan arti laki-laki, tetapi menunjukkan arti menusia dengan jenis tertentu baik laki-laki maupun perempuan. Dalam tafsi jalalain kata tersebut ditafsirkan dengan orang-orang yang tetap bersama Nabi dimana mereka tetap konsisten menyertai perjuangan Nabi Muhammad SAW. Disisi lain menurut syakih as-Shōwi bahwa kata terbut diderevesikan kepada para sahabat yang mengikrarkan untuk senantiasa bersama Rasulullah Saw saat berperang hingga mati syahid di medan pertempuran ${ }^{18}$ Menurut ibn Katsir ayat ini turun setelah selesainya perang uhud dengan kekalahan dan pengorbanan yang diderita pasukan muslim. ${ }^{19}$

Adapun kata al-Nisa, adalah bentuk jama' dari kata al-mar"ah yang berarti perempuan secara umum, dari yang masih bayi sampai yang sudah berusia lanjut. Kata an-nisa" berarti gender perempuan. Dalam al-Quran kata ini terlulang sebanyak 59 kali, dengan klaisifikasi maksud sebagai gender perempuan sendiri sebagai istri-istri. Seperti (Q.S. al-Nisa':7),

17 Muhammad bin Umar bin Zamakhsyari al-Khawarizmy, al-Kassyaf „an Haqoiqi at-Tanzil Wa"uyun al-Aqawil fi Wujuhi at-Ta"wil (Bairut: Darul Fikr, tt), hlm. 403.

18 Ahmad bin Muhammad as-Showi, Hasyiyatu as-Showi „ala Tafsir al-Jalalaini, Mujallad ar-Rabi", vol. 3 (Bairut: Dấr al-Kutub al-Ilmiyyah, 2007), cet. Keempat, hlm. 230.

19. Abû Fidâ Isma'īl Ibn Katsīr, Tafsir al-Quran al-„Adzīm, vol. 3, (Bairut: Dâr al-Fikr, 1986), hlm. 476. 


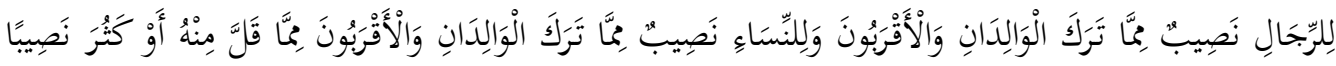

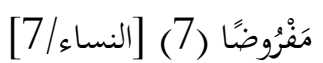

Selain kata al-rijal (laki-laki) dan an-Nisa (perempuan), .struktural istilah gender yang termaktub dalam al-Quran juga bias menggunakan kata adz-dzakar (laki-laki) dan al-untsa/Imra'ah (perempuan). Kata adzdzakar berarti mengisi atau menuangkan, menyebutkan, mengingat, mempelajari, menyebutkan, laki-laki atau jantan. Kata ini lebih berkonotasi biologis (seks) yang bisa digunakan untuk selain manusia ${ }^{20}$. Lawan katanya adalah al-untsa yang disebutkan dalam al-Quran sebanyak 30 kali. Dalam al-Quran, kata ini disebutkan sebanyak 18 kali yang sebagian besar menunjukkan makna laki-laki dari segi biologis, seperti yang tertera dalam Q.S. Ali Imran 3/36 sebagi berikut,

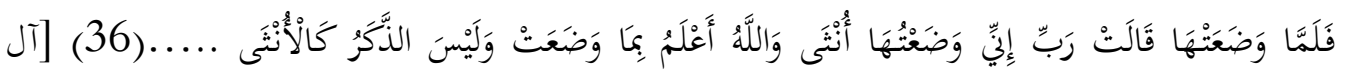

$$
\begin{aligned}
& \text { عمران/36] }
\end{aligned}
$$

"Maka tatkala isteri 'Imran melahirkan anaknya, diapun berkata: "Ya Tuhanku, sesunguhnya aku melahirkannya seorang anak perempuan; dan Allah lebih mengetahui apa yang dilahirkannya itu; dan anak laki-laki tidaklah seperti anak perempuan".

Sedangkan kata Imra'ah berasal dari mara "a yang berarti baik atau bermanfaat. Dari kata ini lahirlah kata mar"u, yang berarti laki-laki dan almarah yang berarti perempuan. Dalam al-Quran kata al-mar"u terulang sebanyak 11 kali yang digunakan untuk pengertian manusia, baik itu lakilaki maupun perempuan. Kata ini menunjukkan pada pengertian manusia dewasa, sesuadah memiliki kecakapan bertindak atau yang sudah berumah tangga. Seperti yang termaktub dalam Q.S. Abasa: 34.

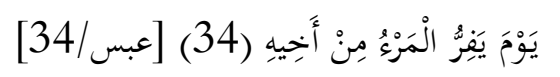

"Pada hari ketika manusia lari dari saudarany"

Dalam pemahaman ayat ini kata mar'u menunjukkan makna lakilaki dan perempuan, dimana mereka pada suatu saat nanti akan disibukkan oleh dirinya sendiri (nanti diakhirat) karena mereka merasa kebingungan ${ }^{21}$.

Bahasa gender dalam al-Quran mempunyai khasanah tersendiri,

20 Waryono Abdul Ghafur, Tafsir Sosial Mendialogkan Teks dengan Konteks, (Yogyakarta: Elsaq Press, 2005), hlm. 107.

${ }^{21}$ Ahmad bin Muhammad,.. hlm. 328. 
sebagian

istilah tersebut spesifik menunjukkan pada aspek laki-laki atau perempuan, dalam

pemaknaan ayat-ayat gender tersebut hendaknya kita mampu mengkaitkan makna interteks atau dengan konsep sintagmatik, dan membandingkan teks yang masih mempunyai keterkaitan dan kesamaan pada ayat lain atau dengan konsep paradigmatic. Konsep paradigmatic sintagmatik dapat juga diaktualisasikan dengan membandingkan beberapa kompilasi ayat-ayat yang mempunyai orientasi sama dengan mengacu pada munasabat al-ayat, asbab an-nuzul, kaidah bahasa, dan mengkaitkan teks dengan konteks secara proporsional.

\section{Kesetaraan Gender dalam Perspektif Islam}

Pada dasarnya semangat hubungan antara laki-laki dan perempuan dalam Islam bersifat adil (equal). Oleh karena itu subordinasi terhadap kaum perempuan merupakan suatu keyakinan yang berkembang di masyarakat yang tidak sesuai atau bertentangan dengan semangat keadilan yang diajarkan Islam. Islam memang mengakui adanya perbedaan (distincion) antara laki-laki dan perempuan, tetapi bukan pembedaan (discrimination). Perbedaan tersebut didasarkan atas kondisi fisik-biologis perempuan yang ditakdirkan berbeda dengan laki-laki, namun perbedaan tersebut tidak dimaksudkan untuk memuliakan yang satu dan merendahkan yang lainnya. ${ }^{22}$

Ajaran Islam tidak secara skematis membedakan faktor-faktor perbedaan laki-laki dan perempuan, tetapi lebih memandang kedua insan tersebut secara utuh. Antara satu dengan lainnya secara biologis dan sosio kultural saling memerlukan dan dengan demikiann antara satu dengan yang lain masing-masing mempunyai peran. Boleh jadi dalam satu peran dapat dilakukan oleh keduanya, seperti perkerjaan kantoran, tetapi dalam peran-peran tertentu hanya dapat dijalankan oleh satu jenis, seperti; hamil, melahirkan, menyusui anak, yang peran ini hanya dapat diperankan oleh wanita. Di lain pihak ada peran-peran tertentu yang secara manusiawi lebih tepat diperankan oleh kaum laki-laki seperti pekerjaan yang memerlukan tenaga dan otot lebih besar. ${ }^{23}$

Emansipasi wanita yang diperjuangkan oleh gerakan feminisme sebenarnya bukan barang baru dalam islam. Pada masa Rasulullah SAW,

22 Nasaruddin Umar, Kodrat Perempuan dalam Islam, (Jakarta: Lembaga Kajian Agama dan Gender, 1999), hlm. 23.

23 Ibid, hlm. 23.

90 JURNAL LISAN AL-HAL 
semangat feminisme juga sempat muncul ke permukaan. Wanita muslilmat pada saat itu menginginkan hak yang sama antara laki-laki dan perempuan. Ummu Salamah pernah mengadu kepada Rasul SAW dengan berkata, " wahai Rasulullah, Kaum pria ikut berperang sedangkan kita (wanita) tidak berperang, kita juga hanya mendapat separo warisan." Dalam tinta sejarah, pada akhirnya peristiwa ini menjadi sebab diturunkannya ayat ${ }^{24}$ :

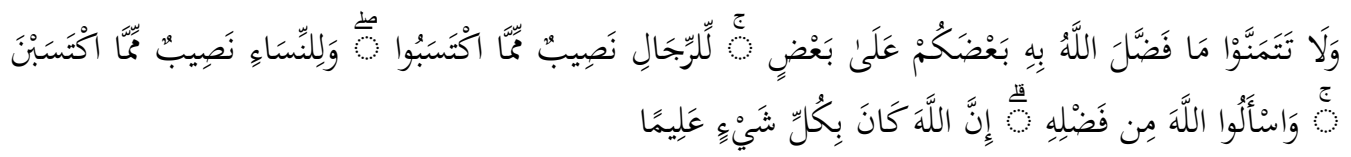

Ada yang berpendapat, ketika Allah menetapkan bagian laki-laki seperti bagian dua wanita dalam warisan, kaum wanita berkomentar, "Kami lebih membutuhkan tambahan daripada kaum laki-laki. Sebab, kami 'kan orang-orang lemah dedangkan mereka orang-orang kuat dan lebih mampu mencari ma'isyah (baca: mata pencahariaan untuk melangsungkan kehdupan) daripada kami." Maka turunlah ayat ini.

Ayat ini menunjukkan bahwa islam dengan tegas menolak. feminisme dan persamaan gender tanpa batas di segala bidang. Sebagai solusinya, islam mengambil langkah bijak dengan cara menunjukan dan mendudukkan wanita pada posisi yang sesuai dengan porsi kewanitaannya, sebagaimana islam mendudukkna kaum pria pada posisi yang sesuai.

Hadirnya agama Islam antara lain untuk menyelamatkan dan membembaskan kaum perempuan dari penindasan-penindasan dimasa jahiliyah. Al-qur'an turun untuk mengangkat harkat dan mertabat serta memberikan hak-hak bagi kaum wanita secara proposional dengan tanpa mengesampingkan nilai-nilai kodrati dalam dirinya. Bagi islam, diskriminasi merupalan sebuah tindakan kejahatan, akan tetapi upaya untuk kesetaraan merupakan bentuk kesesatan. Islam tidak pernah menganggap perempuan lebih rendah ataupun sama dengan laki-laki islam hanya menentukan hak-hak antara keduanya dalam porsi sesuai dengan alamiyah masing-masing. ${ }^{25}$

Imam al-fakhrur razi dalam tafsirnya, memaparkan beberapa faktor yang membedakan antara kaum pria dan wanita sesuai dengan kodrat masing-masing. Antara lain:

${ }^{24}$ Ath-thobari, Tafsir Thobaril (Beirut: dar al fikr) vol. 5, hlm. 46-47.

${ }^{25}$ Ath-thobari, Tafsir Thobaril (Beirut: dar al fikr) vol. 5, hlm. 48. 
a. Laki-laki lebih mempunyai peluang untuk selalu bisa mengabdikan diri untuk beribadah kepada Allah, sedangkan kaum perempuan selalu terhalang dengan kodrat alamiahnya seperti adanya datang bulan (menstruasi/haid), melahirkan, menyusui dan faktor-faktor alamiyah lainnya

b. Dari faktor fisik dan psikologis, tipe laiki-laki dominan lebih kuat, tangguh, tegas dan berani dari pada wanita sehingga laki-laki mampu untuk mencari nafkah, bertanggung jawab, mengambil keputusan dan tugas-tugas yang dianggap lebih beresiko dan peerlu keteguhan jiwa.

c. Laki-laki lebih pantas untuk berinteraksi tanpa harus menanggung aib yang semua itu justru bertentangan dengan psikis dan tabiat wanita yang lemah lembut, penuh kasih sayang dan keibuan. ${ }^{26}$

Pada dasarnya islam tidak melarang kaum hawa untuk turut serta dalam berkarir dan berkerja. Karena mencari harta yang halal adalah suatu kewajiban. Syaikh Abdullah Hamid Al-Jalali menjelaskan adanya beberapa syarat yang harus dipenuhi oleh wanita dalam berkarir. Diantaranya wanita haruslah jauh dari pandangan pria dan percampuran lawan jenis, tidak menyendiri, tidak ada laki-laki selain mahram dan amannya dalam perjalanan. Kalau ada statement yang melarang wanita untuk berkarir karena faktor khauf al-fitnah demi menjaga harkat dan martabat wanita. ${ }^{27}$

Penjelasan di atas memberikan pengertian bahwa ssebenarnya islam sangatlah menghargai dan menjunjung tinggi hak dan martabat kaum hawa. Hal ini sangatlah jelas bila kita mau menengok kembali sejarah kelas awal mula lahirnya islam dimana pada masa jahiliyah wanita disamakan dengan harta yangg bisa diwarits dan di pindah tangankan. Lebih dari itu, kelahiran seorang bayi wanita dianggap suatu aib sehingga masyarakat arab tega mengubur hidup-hidup bayi perrempuannya. Konsep kesetaraan gender antara laki-laki dan perempuan dalam alQur'an, secara garis besar dapat di kelompokkan menjadi 3:

Pertama, laki laki dan perempuan adalah makhluk ciptaan Allah yang mempunyai kewajiban sama makhluk ciptaan Allah yang mempunyai kewajiban sama. (Az Zariyat: 56)

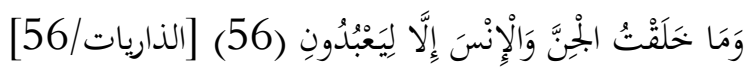

"Dan Aku tidak menciptakan jin dan manusia melainkan supaya mereka

${ }^{26} \mathrm{Al}$-fakhr al-raziy, tafsir fakhr al- raziy (Beirut: dar al-fikr) vol. 8, hlm. 28-29.

${ }^{27}$ Abdullah Hamid Al-Jalali, Fiqh al-Islam vol. 2 (Beirut: Dar al-Fikr), hlm. 365.

92 JURNAL LISAN AL-HAL 
menyembahku"

Dalam kapasitasnya sebagai hamba, tidak ada perbedaan antara laki-laki dan perempuan. Keduanya mempunyai potensi dan peluang yang sama untuk menjadi hamba ideal. Hamba ideal dalam al-Qur'an biasa diistilahkan dengan orang-orang yang bertakwa (muttaqin).

Dan karena kapasitas seorang hamba, maka maksud dan tujuan penciptaan manusia di muka bumi ini adalah di samping untuk menjadi hamba yang tunduk dan patuh serta mengabdi kepada Allah, juga untuk menjadi khalifah di bumi, sebagaimana tersurat dalam Alqur'an (Al-An'am: 165)

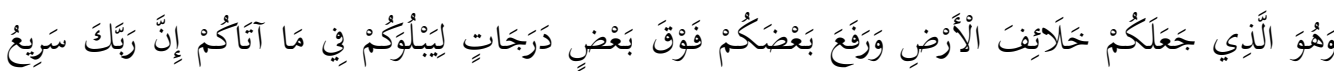

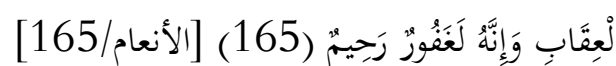

"Dan dialah yang menjadikan kalian penguasa-penguasa di bumi dan Dia meninggikan sebahagian kalian atas sebahagian y ang lain beberapa derjat, untuk mengujimu tentang apa yang diberikanNya kepada kalian. Sesungguhnya Tuhan kalian amat cepat siksaanNya dan sesungguhnya Dia Maha Pengampun lagi Maha Penyayang"

Dan sebagai seorang hamba dan khalifah di bumi. laki-laki dan perempuan berpotensi meraih prestasi. Tidak ada pembedaan antara lakilaki dan perempuan untuk meraih peluang prestasi. Disebutkan dalam Alquran (Al-Nisa: 124)

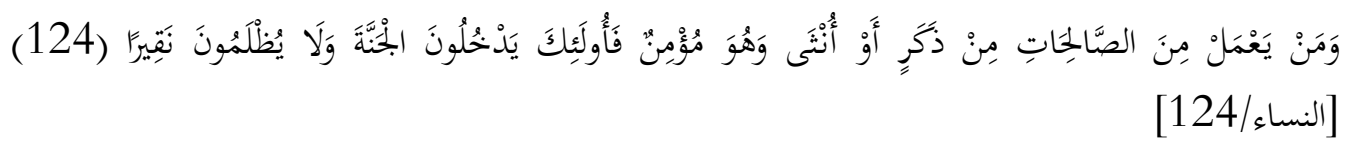

"Barangsiapa yang mengerjakan amal-amal saleh, baik laki-laki maupun wanita sedang ia orang yang beriman, Maka akan kami berikan kehidupan kepada mereka berupa kehidupan yang bagus. Dan akan kami balas mereka dengan pahala yang lebis bagus dari pada yang mereka kerjakan."

Ayat-ayat tersebut mengisyaratkan konsep kesetaraan yang ideal dan memberikan ketegasan bahwa prestasi individual, baik dalam bidang spiritual maupun urusan karir profesional, tidak mesti dimonopoli oleh satu jenis kelamin saja.

Dalam ayat ini, dapat kita pahami, bahwa sosok laki-laki dan perempuan semuanya mempunyai derajat kesamaan dimata social, agama, dan hokum, apabila kita berpijak pad makna dzakari wa untsa bahwa kata ini berimplikasi makna secara biologis, dimana secara kontekstual orientasi bisa diarahkan pada ranah kehidupan social, dimana dalam 
menjalankan kehidupan selazimnya kedua insan tersebut terintegrasi dengan nilai-nilai keimanan atu jiwa norma-norma keagamaan yang begitu baik. Disisi lain, kata dimaknai sebagai pemberitahun eksplisit untuk laki-laki yang kebahagian sebuah sebagai dimaknai حياة طيبةkata adapun ,perempuan dan diperoleh mereka ketika keimanan dan ketaqwaan disatukan dalam wujud ketaatan yang berkesinambungan di dunia ini sehingga berdampak pada pahala di dunia dan akhirat yakni dengan mencukupkan kebahagiaan di dunia sesuai kadar yang dicapai oleh makhluq-Nya dan kebaikan yang tak terhingga di akhirat kelak. Ayat ini memberikan pelajaran yang berarti bagi kaum mukmin dan mukminat bahwa Allah SWT akan memberikan pahala sesuai kadar yang dilakukan oleh hamba-Nya ${ }^{28}$

Kedua tentang hak kepimilikan. kaum perempuan dalam Islam juga memiliki hak-hak ekonomi, yakni untuk memiliki harta kekayaannya sendiri, sehingga dan tidak suami ataupun bapaknya dapat mencampuri hartanya. Hal tersebut secara tegas disebutkan dalam (An-Nisa': 32)

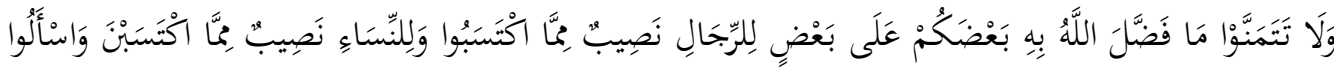

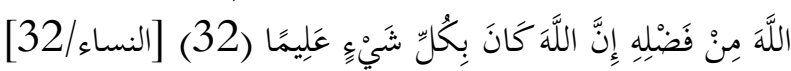

"Dan janganlah kamu iri hati terhadap karunia yang telah dilebihkan Allah kepada sebagian kamu atas sebagian yang lain. (Karena) bagi laki-laki ada bagian dari apa yang mereka usahakan, dan bagi pere mpuan (pun) ada bagian dari apa yang mereka usahakan. Mohonlah kepada Allah seb agian dari karuniaNya. Sungguh, Allah Maha Mengetahui segala sesuatu."

Kepemilikan atas kekayaannya tersebut termasuk yang didapat melalui warisan ataupun yang diusahakannya sendiri. Oleh karena itu mahar atau maskawin dalam Islam harus dibayar untuknya sendiri, bukan untuk orang tua dan tidak bisa diambil kembali oleh suami. ${ }^{29}$

Sayyid Qutb menegaskan bahwa tentang kelipatan bagian kaum pria dibanding kaum perempuan dalam hal harta warisan, sebagaimana yang tertulis dalam al-Qur'an, maka rujukannya adalah watak kaum pria dalam kehidupan, ia menikahi wanita dan bertanggung jawab terhadap nafkah keluarganya selain ia juga bertanggung jawab terhadap segala sesuatu yang berkaitan dengan keluarganya itu. Itulah sebabnya ia berhak

28 Muhammad bin Umar bin Zamakhsyari al-Khawarizmy, Loc. Cit...,Vol 2, hlm. 427.

29 Mansour Fakih, Analisis Gender dan Transformasi Sosial, (Yogyakarta: Pustaka Pelajar, 1997), hlm. 37-67.

94 JURNAL LISAN AL-HAL 
memperoleh bagian sebesar bagian untuk dua orang, sementara itu kaum wanita, bila ia bersuami, maka seluruh kebutuhannya ditanggung oleh suaminya, sedangkan bila ia masih gadis atau sudah janda, maka kebutuhannya terpenuhi dengan harta warisan yang ia peroleh, ataupun kalau tidak demikian, ia bisa ditanggung oleh kaum kerabat laki-lakinya. Jadi perebedaan yang ada di sini hanyalah perbedaan yang muncul karena karekteristik tanggung jawab mereka yang mempunyai konsekwensi logis dalam pembagian warisan. ${ }^{30}$

Ketiga, ialah kesetaraan baik laki-laki maupun perempuan agar berilmu pengetahuan dan tidak menjadi orang yang bodoh. Allah sangat mengecam orangorang yang tidak berilmu pengetahuan, baik laki-laki maupun perempuan. Sebagaimana (az-Zumar: 9).

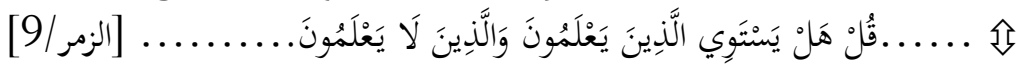

"Katakanlah (wahai Muhammad), Apakah sama seseorang yang mengetahui dan yang tidak mengetahui."

Ayat di atas juga di dukung hadits Nabi SAW

$$
\text { طالب العلم فريضة علي كل المسلمين و المسلمات }
$$

"Menuntut ilmu itu wajib atas setiap laki-laki dan perempuan". (HR. Muslim)

Ayat-ayat tersebut mengisyaratkan konsep kesetaraan yang ideal dan memberikan ketegasan bahwa prestasi individual, baik dalam bidang spiritual maupun urusan karir profesional, tidak mesti dimonopoli oleh satu jenis kelamin saja.

Dengan demikian dapat dikatakan bahwa Islam justru menumbangkan suatu sistem sosial yang tidak adil terhadap kaum perempuan dan menggantikannya dengan sistem yang mengandung keadilan. Islam memandang perempuan adalah sama dengan laki-laki dari segi kemanusiannya. Islam memberi hak-hak kepada perempuan sebagaimana yang diberikan kepada kaum laki-laki dan membebankan kewajiban yang sama kepada keduanya.

\section{Simpulan}

Mengenai gender pada dasarnya dalam konsep islam telah dijelaskan baik secara tersirat maupun tersurat; terutama merujuk kepada

30 Sayyid Quthb, Keadilan Sosial Dalam Islam, (Bandung, Penerbit Pustaka, 1984), hlm. 71-74. 
al-Qur'an, konsep keseteraan gender mengisyaratkan 2 (dua) pengertian. Pertama, al-Qur'an mengakui martabat pria dan wanita dalam kesejajaran tanpa membedakan jenis kelamin. Kedua, pria dan wanita mempunyai hak dan kewajiban yang sejajar disegala bidang. akan tetapi pandangan inferior bahwa perempuan adalah makhluk yang lemah juga disosialisasikan atas nama agama.

Pada esensinya, hadirnya agama Islam untuk menyelamatkan dan membembaskan kaum perempuan dari penindasan-penindasan dimasa jahiliyah. Al-qur'an turun untuk mengangkat harkat dan mertabat serta memberikan hak-hak bagi kaum wanita secara proposional dengan tanpa mengesampingkan nilai-nilai kodrati dalam dirinya. Meski banyak kalangan inferior yang menyatakan bahwa islam mendeskriminaskian perempuan; jika merujuk pada sejarah jahiliyah, islam hadir untuk memulyakan perempuan dengan batas yang telah ditentukan. Karena memang secara kodrati antara laki-laki dan perempuan mempunyai bentuk fisik dan keadaan psikis yang berbeda.

\section{DAFTAR PUSTAKA}

Abdul Ghafur, Waryono, Tafsir Sosial Mendialogkan Teks dengan Konteks, Yogyakarta: Elsaq Press, 2005.

Ali, Satabik dan Muhdhor, Ahmad Zuhdi, Kamus Kontemporer ArabIndonesia, Yogyakarta: Multi Karya Grafika, 1998.

al-Khawarizmy, Muhammad bin Umar bin Zamakhsyari, al-Kassyaf „an Haqoiqi at-Tanzil Wa"uyun al-Aqawil fi Wujuhi at-Ta"wil, Bairut: Darul Fikr.

al-raziy, Al-fakhr , tafsir fakhr al- raziy, Beirut: Dar al-fikr, 2002.

Arfa, Faisar Ananda, Wanita dalam Konsep Islam Modernis, Jakarta: Pustaka Firdaus, 2004.

Ath-thobari, Tafsir Thobaril, Beirut:dar al fikr, 2003.

az-Zuhaili, Wahbah, Fiqh al-Islamiy wa Adilatuh, Beirut :Dar al-Fikr, 1989.

Bashin, Kamala, What is Patriarchy, Diterjemahkan "Menggugat Patriarki" oleh Nursyahbani Katjasungkana, Yogyakarta: Yayasan Bentang Budaya, 1996.

Fadhil Lubis, Nur Ahmad, Yurisprudensi Emansipatif, Bandung: Citapustaka Media, 2003.

Hamid Al-Jalali, Abdullah, Fiqh al-Islam, Beirut: Dar al-Fikr, 2005.

Ibn Katsīr, Abû Fidâ Isma'īl, Tafsir al-Quran al-„Adzīm, Bairut: Dâr al-Fikr, 1986.

96 JURNAL LISAN AL-HAL 
Mansour Fakih, Analisis Gender dan Transformasi Sosial, Yogyakarta: Pustaka Pelajar, 1997.

Muawanah, Elfi, Menuju Kesetaraan Gender, Malang: Kutub Minar, 2006.

Muhammad as-Showi, Ahmad bin, Hasyiyatu as-Showi „ala Tafsir alJalalaini, Mujallad ar-Rabi", vol. 3, Bairut: Dấr al-Kutub al-Ilmiyyah, 2007.

Nasaruddin Umar, Argumen Kesetaraan Gender Perspektif Al-Qur'an, Jakarta: Paramadina, 1999.

Rachman, Budhy Munawar, Islam Pluralis Wacana Kesetaraan Kaum Beriman, Jakarta: Paramadina.

Ritzer, George and Douglas J. Goodman, Modern Sociological Theory, $6^{\text {th }}$ Edition, diterjemahkan, Teori Sosiologi Modern, oleh Alimandan Jakarta: Prenada Media, 2003.

Umar, Nasaruddin, Kodrat Perempuan dalam Islam, Jakarta: Lembaga Kajian Agama dan Gender, 1999. 